\title{
Federal conservation units in the Brazilian Amazon coastal zone: an adequate
}

\section{approach to control recreational activities?}

Rubem Manoel Coelho Pessoa ${ }^{\mathrm{a}}$, José A. Jiménez ${ }^{\mathrm{b}}$, Rauquirio Marinho da Costa ${ }^{\mathrm{c}}$, Luci Cajueiro Carneiro Pereira ${ }^{\mathrm{d}^{*}}$,

aUniversidade Federal do Pará, Instituto de Estudos Costeiros, Laboratório de Oceanografia Costeira e Estuarina, Alameda Leandro Ribeiro sn, Aldeia, 68600-000, Braganca-Pará, Brazil. E-mail: rubempessoa@yahoo.com.br

bUniversitat Politècnica da Catalunya, Laboratori d'Enginyeria Marítima, Calle Jordi Girona, 1-3, 08034, Barcelona, Spain. E-mail: jose.jimenez@upc.edu.

cUniversidade Federal do Pará, Instituto de Estudos Costeiros, Laboratório de Plâncton e Cultivo de Microalgas, Alameda Leandro Ribeiro sn, Aldeia, 68600-000, BragancaPará, Brazil. E-mail: raucosta@ufpa.br.

dUniversidade Federal do Pará, Instituto de Estudos Costeiros, Laboratório de Oceanografia Costeira e Estuarina, Alameda Leandro Ribeiro sn, Aldeia, 68600-000, Braganca-Pará, Brazil. E-mail:cajueiro@ufpa.br.

*Corresponding Author: Luci Cajueiro Carneiro Pereira. E-mail: cajueiro@ufpa.br. Present address: Universitat Politècnica da Catalunya, Laboratori d'Enginyeria Marítima, Calle Jordi Girona, 1-3, 08034, Barcelona, Spain. 


\section{INTRODUCTION}

Coastal tourism usually is of enormous interest to local coastal communities due to its potential for the creation of jobs and the generation of income. Within this context, beaches are the main resource since they comprise a rich diversity of natural ecosystems and landscapes, as well as historical and cultural features, such as local gastronomy (Coccossis and Mexa, 2004; Zolfani et al., 2015).

In general, beaches are the primary focus of coastal tourism. However, the quality and availability of beach recreational activities will depend on a range of factors such as its natural attractions (water quality, landscapes, degree of environmental protection), physical qualities (coastal processes, geomorphology and climate), and touristic facilities e.g., infrastructure, services, accessibility, and safety (Jiménez et al., 2007; Gavio et al., 2010).

Recreational activities may be affected negatively when no regulatory policies are implemented to guarantee either the quality of the beach or visitor satisfaction. Adequate coastal management planning and public policies for the development of tourism are essential to avoid or mitigate impacts caused by both natural and anthropogenic processes. These policies should be applied by policy makers, the private sector, tourists, and local residents (Araújo and Costa, 2008; Lucrezi et al., 2017).

The $8,500 \mathrm{~km}$ of the Brazilian coastline encompasses an enormous cultural diversity, a rich biodiversity, and a variety of natural environments, including fluvial, estuarine, and oceanic beaches. Brazilian beaches are often included in published lists of top tourist destinations, due to the country's tropical climate and the attractive features of its beaches, which range from the famous urban sites of Rio de Janeiro to the wild, isolated beaches of the Amazon region (Szlafsztein, 2009; Mitur, 2010). 
The natural features (e.g., climate and coastal processes) of the beaches located on the Amazon coast of northern Brazil are completely different from those found typically at higher latitudes. Most of these beaches are located within conservation units, and are well-preserved natural environments, with considerable potential for leisure and recreational activities (Oliveira et al., 2011; Silva et al., 2011).

Along the Amazon coast, sandy beaches are found primarily in the Brazilian states of Pará and Maranhão, while muddy beaches predominate in the coast of Amapá, due to the large quantities of fine sediment supplied by the Amazon River. Much of this coastline is sparsely populated or even uninhabited in such a way that most of beaches can be classified as natural (rural) or semi-natural ones, with some urban beaches in densely-populated areas. Anthropogenic pressures and conflicts accessed on the beaches include (i) the unregulated occupation of land, in particular in mangroves, and on dunes and cliffs, and (ii) the presence of cesspits, solid garbage and illegal sewage outfalls in the mangrove or intertidal zone, and on dunes (Szlafsztein, 2009; Pereira et al., 2018).

The observed increased use of Amazon beaches which leads to an increase in the frequency and intensity of these conflicts (e.g., Pereira et al., 2014, 2018), highlights the urgent need for the implementation of adequate coastal management plans for the Amazon littoral. In this sense some attempts, such as state and municipal coastal management programs, and the Promenade project, have been implemented, but have yet to produce satisfactory results (Szlafsztein and Sterr, 2007; Szlafsztein, 2012). On the other hand, the creation of a number of federal conservation units (FCUs), in particular marine extractive reserves (known as Reservas Extractivistas Marinhas or RESEXes), has had a positive effect on the management of a range of environments on the Amazon coast. Federal Conservation Units are part of the National System of Conservation Units created by Law 9,985 of 18 July 2000 to devise a plan for sustainable development and land conservation. A brief summary showing the categories, competences and types of FCUs, as well as the role of the Extractive Reserves are presented in Table 1. 
$<$ Insert Table 1>

The inclusion of traditional populations has been a major theme of the creation of FCUs on the coast of the state of Pará. This approach is considered to be an excellent strategy for the preservation of genetic, cultural, and natural resources, and the maintenance of existing physical processes and social dynamics (Rodrigues and Szlafsztein, 2011). A total of eight RESEXes are found in Pará, and they all play a fundamental role in the management of the space used by traditional populations, in particular fishing communities (Moreira and Silva, 2012). In recent decades, however, increasing pressure from a large number of stakeholders, with interest in the development of recreational activities has generated both social conflicts, such as the loss of the identity of traditional local populations, and environmental problems, including overcrowding, erosion, and contamination (Pereira et al., 2014, 2018).

Recreational activities in Pará beaches involve sunbathing, aquatic activities (such as bathing, swimming, surfing, wind surf, and ride with banana boat and jet ski), cultural events, ecotourism and fishing practices (Bentes et al., 2012; Almeida and Jardim, 2018; Pereira et al., 2018), and they mostly concentrate during weekends of July (scholar vacation period) and bank holidays, mainly during the dry season (Pessoa et al., 2016; Sousa et al., 2017). It is important to note that recreational activities in Pará sandy beaches is a relatively recent use (around 3-4 decades ago) in comparison with the rest of the Brazilian coast, and it was driven by the construction of roads connecting largest cities to the coastline. Currently, a small number of roads $(<10)-$ considering the more of $2000 \mathrm{~km}$ of Pará coastline - allows the access of thousands of beachgoers to many sandy beaches causing overcrowding during peak periods. Conversely, the creation of the FCUs is of less of 2 decades.

All these facts together, added to the efforts of the private sectors to expand the coastal tourism without management plans, including those of the Extractive Reserve - such as in Ajututeua (one of the study areas) can generate a new scenario, where traditional uses will become abandoned 
and marine extractive reserves will lost the most effective option for the conservation of the beaches used for recreational activities in the Amazon coastal zone.

To evaluate the role of these protective administrative figures to reduce/manage the effects of intense recreational activities on the Amazon coast, the present study investigates the natural processes, anthropogenic problems, and social conflicts of two rural sandy beaches located within two Marine Extractive Reserves.

\section{STUDY AREA, MATERIALS AND METHODS}

\subsection{General Setting}

The Brazilian Amazon Coast is 2,250 km long, and occupies approximately one third of the country's coastline, in the northern states of Amapá, Pará, and Maranhão. This coast is characterized by semi-diurnal macrotides and the presence of dozens of estuaries, including that of the Amazon River itself. This coast also includes one of the world's largest continuous tracts of mangroves forest, and has a wide array of islands, peninsulas, bays, deltas, and beaches (Souza Filho et al., 2005).

The $600 \mathrm{~km}$-long coast of Pará encompasses 30 municipalities between the mouth of the Amazon River and Gurupi Bay. This coast can be divided into three sectors, based on its local geomorphological features: (i) the Atlantic coast - Sector 1, known as the "Salgado Paraense", (ii) the Inner Estuarine Coast - Sector 2, and (iii) the Continental Estuarine Coast - Sector 3 (Fig. 1A). This area has approximately 3.5 million inhabitants (IBGE, 2018).

The study area comprises sectors (1) and (2). Both sectors are dominated by the typical humid equatorial climate of the Amazon region, with two well defined seasons, a rainy period, between January and June, and a dry season, from July to December. Mean temperatures range from $26^{\circ} \mathrm{C}$ to $29^{\circ} \mathrm{C}$, while annual rainfall is approximately $2,500 \mathrm{~mm}$, with $75-85 \%$ of the precipitation typically falling between January and May (Moraes et al., 2005). Winds also vary seasonally, with stronger northeaster lies being recorded during the dry season and more moderate south easterlies during the rainy season. Monthly maximum wind speeds range up to $8.0 \mathrm{~m} / \mathrm{s}$ (INMET, 2018). 
$<$ Insert Figure 1>

\subsection{Study Beaches}

Two beaches, Pesqueiro and Ajuruteua, are analyzed in this study. Pesqueiro is an estuarine beach located on the eastern side of Marajo Island, and is approximately $4 \mathrm{~km}$ long and $1 \mathrm{~km}$ wide (Fig. 1B). This beach is bordered by tidal flats, running North-South (França and Souza Filho, 2003). Pesqueiro beach is located within the Soure Marine Extractive Reserve which includes three traditional fishing villages, with a total population of some 400 inhabitants. That beach attracts large numbers of beachgoers over the course of the year, and the highest flux of visitors (more than 50.000) is observed during the school vacation in July (Brasil, 2001). Most local inhabitants earn a living from artisanal fishing and tourism (Souza, 2008; Lobato et al., 2014).

Ajuruteua beach (Fig. 1C), in turn, is an oceanic beach located between two tidal channels within the Caeté-Taperaçú Marine Extractive Reserve (Brasil, 2005; ICMBio, 2012). It is a rural beach with considerable touristic potential, which is visited by thousands of beachgoers, in particular during the July school vacation, when the total number of beachgoers may reach almost 100,000 , and public holidays (Pereira et al., 2009; Pessoa et al., 2013). There are approximately 300 local residents, who make a living from artisanal fishing and tourism. Local public services and infrastructure are either inadequate or absent, local buildings are precarious, and areas of mangrove and dunes have been occupied (Pereira et al., 2007). As a consequence, the area is impacted by erosion, pollution, and overcrowding during the peak periods of visitation (Sousa et al., 2011; Pereira et al., 2014).

\subsection{Study period, methodological approach, and the variables analyzed}

\subsubsection{Study period}


To characterize main natural and anthropogenic related variables in the study area, field campaigns were timed to coincide with main recreational periods, i.e., school vacations and public holidays. The campaigns were distributed in both the rainy and dry seasons to properly reflect the seasonality of the region (Table 2).

$<$ Insert Table 2>

\subsubsection{Environmental Features}

Climatic data (rainfall and air temperature) were obtained from the Bragança (A226) and Tracuateua (UTC 82145) stations of the Brazilian Institute of Meteorology for Ajuruteua beach, and the Soure station (UTC 82141) for Pesqueiro beach. Data on monthly rainfall rates and mean monthly temperatures were obtained, based on hourly readings, between January and December, 2013, at Ajuruteua and between January 2015 and December 2016 at Pesqueiro.

Water properties data were collected using a CTD with a turbidity sensor. Temperature, salinity, and turbidity measurements were taken every $10 \mathrm{~min}$. Water samples were obtained using Niskin oceanographic bottles from approximately $1.0 \mathrm{~m}$ below the surface in bathing areas every 3 h. These samples were analyzed to determine hydrological $(\mathrm{pH}$, dissolved nutrient concentrations and chlorophyll-a) and microbiological (thermotolerant coliform) parameters.

In the laboratory, dissolved inorganic nutrients (nitrite, nitrate and orthophosphate) were analyzed according to the Strickland \& Parsons (1972) and Grasshoff et al. (1983), and chlorophyll- $a$ concentrations were determined by the procedures described by Parsons \& Strickland (1963) and UNESCO (1966). Filtered water samples were also frozen for later analysis of total dissolved phosphorus (TDP). The TDP values were determined by applying an adaptation of the simultaneous oxidation of phosphorus compounds using an alkaline persulfate-oxidizing solution (Grasshoff et al. 1999). 
Thermotolerant coliform concentrations were determined by the multiple tube fermentation technique (APHA, 2004). The quality of the water used for bathing and other recreation activities was evaluated through comparisons with the recommended thresholds established by the Brazilian Ministry of the Environment (CONAMA, 2000, 2005).

\subsubsection{Human features}

Data on recreational use were based on counts of the number of people on the beach, while territorial occupation was analyzed by direct observation, and local facilities were evaluated using check lists and photographs. Transects located near beach access ways were walked to count the number of beachgoers, divided in three zones: (i) zone 1, the backshore or promenade area, in which facilities such as bars and restaurants are located; (ii) zone 2, the intertidal zone, which is occupied according to tidal conditions (high/low, spring/neap tides); (iii) zone 3, the surf zone, which includes bathing areas. During each campaign, the number of beachgoers occupying each pre-established transect was counted every hour during the day (Fig. 1.D-E).

The Recreational Carrying Capacity (RCC) was estimated following Ruschmann (1999) and Eugênio-Martin (2004), after adaption to the meso-macrotidal characteristics of the study beaches. The RCC was calculated based on the density of beachgoers in each zone: $\mathbf{R C C}=\mathbf{V} / \mathbf{K}$, where $\mathbf{R C C}$ is the Recreational Carrying Capacity, $\mathbf{V}$ is the area available for use, and $\mathbf{K}$ is the number of beachgoers.

Data on the occupation of land (mangroves, and intertidal and dune zones) were recorded by direct observation. Facilities (infrastructure, services, and access ways), and information on the presence of garbage, sewage and other effluents, and domestic (horses and dogs) and potentially dangerous aquatic animals (jellyfish and fish with stingers) were registered through the application of check lists and the acquisition of photographic records.

All this information was used to identify local hazards and risks. Social conflicts resulting from recreational activities were analyzed according with the perspectives for sustainable use of the 
units of conservation in which each beach is located. Recommendations for the management of recreational activities in the study areas are also provided.

\section{RESULTS}

\subsection{Environmental Features}

Mean air temperatures on the Amazon coast are in the $26-29^{\circ} \mathrm{C}$ range (Figure 2) throughout the year, and do not limit recreational activities in any way. However, the high rainfall rates of the first half of the year do affect recreational activities. During the study period, the rainiest months were March (342.3 mm) and April (326.5 mm) at Ajuruteua, and February (450.5 mm) and March (552.1 mm) in 2016 at Pesqueiro. During the second half of the year, however, monthly rainfall ranged from $0 \mathrm{~mm}$ to $80 \mathrm{~mm}$, and did not affect recreational activities (Figure 2).

\section{$<$ Insert Figure 2>}

The salinity of the water varied from brackish at Pesqueiro beach to brackish - saline at Ajuruteua, while the $\mathrm{pH}$ was practically neutral throughout the study period at both sites. Most values recorded for turbidity and nutrient concentrations (nitrite, nitrate, and total phosphorus) exceeded the thresholds recommended by CONAMA (Table 3).

$<$ Insert Table 3>

\subsection{Recreational use}

The spatial distribution of the recreational use of the beaches depends primarily on tidal conditions (high vs. low, spring vs. neap), which determine the width of the intertidal zone at any given time. The backshore zones of both beaches are occupied primarily by bars and restaurants, while at Ajuruteua, this zone is also occupied by guesthouses and musical attractions. At low tide, 
the intertidal zone accommodates the majority of beachgoers, and this part of the beach is used for sports (e.g., soccer) and sunbathing, and is also occupied by bar tables. The surf zone is used by bathers, and at Ajuruteua, it may be also used for water sports (e.g., surfing, sailing, boating) and fishing. As Pesqueiro is estuarine, parts of the intertidal and surf zones are covered by mud, and are avoided by bathers during the ebb and low tide.

The number of beachgoers on a beach at any time depends primarily on four factors: (i) wheather (i.e., rainy or sunny), (ii) the type of period (school vacation or public holiday), (iii) the day of the week (weekday or weekend), and (iv) time of the day. In general, the numbers of visitors in the Ajuruteua beach is larger than in Pesqueiro (Figure 3A-B). During the school vacation period, zone 1 of both beaches may be occupied by more than 1000 beachgoers. On public holidays, Ajuruteua tends to have more visitors during the dry season (Figure 3C), while Pesqueiro tends to have more visitors in the rainy season. This different behavior is because it is closer to the Pará state capital, Belém (Figure 3D) and to arrive in Marajó Island from Belém is quite faster and easier. During the school vacation period, overcrowding was observed at both beaches during weekends $\left(\mathrm{CCR}<4 \mathrm{~m}^{2} /\right.$ visitor). Peak visitation rates were recorded on Sunday afternoons during the school vacation. At Ajuruteua, the peak was between 13:00 h and 14:00 h (Figure 3E), given that the majority of beachgoers return to their hometowns by car immediately afterward. At Pesqueiro, the peak is later, between 14:00 $\mathrm{h}$ and 15:00 $\mathrm{h}$ (Figure 3E), due to the ferryboat timetable.

\section{$<$ Insert Figure 3>}

\subsection{Use conflicts}

The unregulated occupation of intertidal zones, and areas of dunes and mangrove are prohibited under federal legislation because they are highly vulnerable to natural and anthropogenic processes, usually resulting in erosion problems. Thus, when human occupation is taking place in the outer part of these highly dynamic areas without a proper planning, the process usually end ups with 
buildings and structures being affected. This, in turn, will drive the construction of protection structures (usually also without a proper planning) which will modify local dynamics and may enhance erosion of adjacent areas and, frequently, being responsible for the destruction of houses and infrastructures, and the degradation of the coastal environment.

In most cases, rural beaches have rudimentary facilities, in particular when located in the vicinity of conservation units. There are no mandatory laws regulating the type of infrastructure within these RESEXes. However, due to large tide ranges, local building (houses, hostel, bars) are normally of wooden and palafita type. At Ajuruteua, the local Civil Defense has closed bars and guesthouses because they are affected by direct wave action due to shoreline erosion, although part of the ruins from these buildings remains on the beach, where it traps and accumulates debris and garbage (Figure 4A). Seawalls have been built by owners of bars and hotels in some places to control the erosion of infrastructure (Figure 4B). Natural erosive processes are common on Amazon beaches and, while buildings are scarce on Pesqueiro beach, these processes are affecting local mangroves (Figure 4C). No access for beachgoers with physical disabilities (Figure 4D) was found.

\subsection{Natural and Anthropogenic Hazards}

A range of potential hazards were observed on both study beaches. Among the anthropogenic-related hazards, the lack of a public sanitation system has caused contamination at Ajuruteua, and sewage (Figure 5A) and solid waste (Figure 5B) are common sources of contamination. Solid waste includes plastics, glass, cans, paper, and animal excrement. The rudimentary cesspits built within the intertidal zone also have highly negative effects on water quality, in particular during vacation periods, when the number of beachgoers peaks, and especially, during the high tide when the pits are flooded. No cesspits have been built in the intertidal zone at Pesqueiro, which is reflected in the excellent quality of the local water in terms of thermotolerant coliforms (Table 4). 
No Amazonian beaches are zoned for aquatic activities and water sports, such as banana boat, kite surfing and jet skiing (Figure 5D). This aspect together the reduced numbers of lifeguards and police, make these areas very hazardous for beachgoers, especially given the lack of first aid services, and the fact that the nearest medical facilities are located at a long distance from the beach. At both study beaches, the total lack of signposting or zoning further increases the potential risks for beachgoers.

In addition, natural hazards include the region's moderate to high hydrodynamic energy (tides, waves, currents) and the presence of potentially dangerous animals, such as stingrays and jellyfish. Accidents are more frequent during periods of high hydrodynamic energy, in particular, the equinoctial spring tides, which coincide with Easter and Brazilian Independence Day, and in particular. during the school vacation period, when the numbers of drowning increases (personal communication from local lifeguards). In addition to this, Pesqueiro beach is affected by the presence of animals such as buffalos, dogs and horses (Figure 5C).

\author{
$<$ Insert Table 4> \\ $<$ Insert Figure 4> \\ $<$ Insert Figure 5 $>$
}

\title{
3.5 Regulatory Measures
}

Federal, state or municipal levels, are scarce on the Amazon coast, leaving the region exposed to private economic interests. To avoid conflicts and losses, it would be necessary to implement a far-reaching set of measures in various areas, including the economic sector (fishing, tourism, commerce, services), public agencies (ICMBio - Chico Mendes Institute for Biodiversity Conservation, SEMAS - Secretariat of the Environment and Sustainability, security forces), 
scientific institutions (universities, research groups), government authorities, local residents, visitors, and NGOs, as well as to distribute benefits and profits.

Federal Conservation units have their own specific legislation, which has contributed to the regulation of different economic activities on the Amazon coast, including tourism, which can only be totally positive when it includes measures for the protection of local environments and the sociocultural sustainability of traditional local communities. The present study focused on the areas of the Caeté-Taperaçu and Soure Marine Extractive Reserves. These conservation units play an important role in the protection of traditional fishing communities, local biodiversity, the natural landscape, and the sustainable development of tourism.

In the 42,069 hectare Caeté-Taperaçu Marine Extractive Reserve (which was created by federal decree on May 20th, 2005), the sustainable use of natural resources is focused primarily on the mangrove forest, which has suffered a certain level of deforestation, and other impacts, such as overfishing. Ajuruteua beach is within a distinct zone of the reserve, and is excluded from the strict protection of the conservation unit. The traditional local communities have a tourism-based economic model, which lacks adequate planning. The lack of any effective municipal management initiatives and the absence of adequate communication between local residents, visitors, the owners of local establishments (guesthouses, bars, and shops), the scientific community, and local authorities, have generated a series of environmental and social problems, despite the establishment of the Municipal Coastal Management Working Group (GT-GERCO Bragança).

The sustainable use of natural resources in the 27,464 hectare Soure Marine Extractive Reserve (created by federal decree on November 23rd, 2001) is also focused on the mangrove, although the traditional local communities support the development of sustainable ecotourism. These communities have the right to use the natural resources of Pesqueiro beach as a source of subsistence, combined with tourism activities, which are regulated by the ICMBio, the federal environment agency responsible for the reserve. In this case, the effective communication among different social actors, the scientific community, ICMBio, and other government authorities has resulted in 
negligible environmental and social problems, as shown by the results of the present study. A management program $\left(\mathrm{n}^{\circ}\right.$ 02070.012546/2017-61) was elaborated based on a participative and integrated approach.

Another federal regulatory measure is the National Coastal Management Plan (PNGC) through the Federal Law No. 7.661, de 16/05/88 that aims to promote rational use of the coastal zone resources, in order to raise the population quality of life, and to protect its natural, historic, ethnic and cultural heritage. The state coastal zone management program (GERCO/Pará, State Decree No. 1,759-2017) is currently being elaborated by the state through the Secretariat of the Environment and Sustainability. The elaboration of the GERCO/Pará will allow the elaboration of municipality programs. The elaboration of the municipality coastal management programs is urgently necessary and will propose specific actions in coastal areas, including those located in RESEX areas, such as Soure and Bragança.

While the management program of the Caeté-Taperaçu Marine Extractive Reserve, and the state and municipality coastal management programs where not elaborated, the Clean Beach Project became an important initiative that focuses on environmental education and waste disposal. In Pará state, the project is organized by Federal Universities and clean actions occur during the school vacation period (July month). Approved by the Ministry of Education, it is part of the Protection of the Amazon Coastal Zone Program (PPZCA), and its goal is to guarantee the awareness of visitors, residents and bar owners. This project has been developed in Soure and Ajuruteua.

Unfortunately, at the municipal level, neither of the study beaches have effective protection from executive plans or other legislation, for problems such as erosion, pollution, unregulated land use, and pressure from tourism that is more expressive in Ajuruteua beach. One rare, positive step was the establishment of Bragança municipal law no. 4.148/2011, which prohibits the access of motor vehicle to the intertidal zone of Ajuruteua beach, thus avoiding accidents. 


\section{DISCUSSION}

Beach tourism on the Amazon coast is limited by the long and intense rainy season, the relative isolation of most beaches, as well as the low quality of local services and infrastructures (Pereira et al., 2009; Pessoa et al., 2013; Sousa et al., 2017). As most of the Amazon coastal zone is legally protected by conservation units, as the Marine Extractive Reserves, where recreational activities tend to occur within these areas. However due to the lack of an effective management plan in the Caeté-Taperaçu RESEX, negative implications for traditional cultural values of local population and for the sustainable use of local natural resources are frequently observed in Ajuruteua. On the other hand, in Soure, recreational activities are managed by ICMBio and local community, and decisions are made within the framework of the management plan of the Soure RESEX. In what follows, we discuss natural and anthropogenic conditions of the study beaches and conflicts arising from recreational beach activities. We focus on the role of federal extractive reserves as a regulatory framework for protecting beach environments while also assuring the recreational use of these areas.

\subsection{Natural conditions}

The access the Amazon beaches is limited by many natural aspects that will be discussed here. Primarily, most Amazon beaches are located within areas of mangrove forest that are crisscrossed by estuaries, channels, and creeks, which often limit access by road. The most isolated beaches - such as Ajututeua and Pesqueiro - are typically located at distances of dozens or even hundreds of kilometers from major urban centers and are often only accessible by boat or airplane - such as Pesqueiro (Pinto et al., 2011; Pereira et al., 2018). Even where boat access is available, it is often limited by tidal or seasonal factors, and may be restricted to certain days of the week.

Another limitation is the weather. Both studied beaches are subject to similar climatic and hydrodynamic conditions, including high and stable temperatures, high rainfall levels, mesomacrotides, strong currents, and moderate wave heights (França and Souza Filho, 2003; Pereira et al., 2016). While the high and constant ambient temperatures do not limit recreational activities, the 
seasonal rains tend to restrict a majority of these activities to the second half of the year, when only $10-20 \%$ of the total annual precipitation is typically recorded (Moraes et al., 2005). These factors all contribute to the extreme concentration of visitors (overcrowding) on specific beaches or parts of beaches, in particular during school vacation weekends and holiday sunny periods when more people have time to go to the beach and the weather is better.

The level of the tide may further reinforce overcrowding, with rising tides forcing beachgoers to the backshore zone (Sousa et al., 2011; 2016; Pessoa et al., 2013). There, the high hydrodynamic energy can be a danger to bathers due to the risk of drowning. The tidal amplitudes on the Amazon coast are among the world's greatest, and are responsible for strong tidal currents (Pereira et al., 2016). Nearshore wind waves are modulated by the tidal amplitude over the sandbanks, and the propagation of offshore waves with longer height along the shoreline occurs during the high tide (Pereira et al., 2014). Extreme hydrodynamic conditions are recorded primarily during the high equinoctial spring tides, that is, in March-April and September-October, a period that coincides with public holidays such as Easter and Independence Day. The lowest hydrodynamic are recorded during low tide, primarily in June and July, which coincides with the school vacation (Sousa et al., 2011; Pessoa et al., 2016).

The hydrological characteristics of this equatorial coastal region are completely different from those found at higher latitudes, in particular in the extremes of climate and hydrodynamic conditions. This fact makes this region less attractive in terms of national or international tourism. Water temperatures are high and stable, although salinity varies seasonally. Oceanic beaches, like Ajuruteua, are dominated by marine conditions, and salinity may reach 38 during periods of low rainfall and fluvial discharge, between October and December (Oliveira et al., 2011). During the rainy season, however, salinity may fall to 5, typically between April and June (Pereira et al., 2013). By contrast, Pesqueiro is an estuarine beach influenced primarily by the discharge of the Pará River, with salinity ranging from zero to 10 between the rainy and dry peaks (Costa et al., 2013). 
Turbidity, chlorophyll $a$, and dissolved nutrient concentrations were all consistent with the hydrological patterns of the Amazon Coast, but exceed the limits established by CONAMA for recreational use as described in previous studies by Sousa et al. (2017). The vast number of estuaries found on the Amazon coast, and the extensive area they drain, are the principal factor determining the high turbidity of the region's waters - a negative aspect in order to attract tourist of other region (Pereira et al., 2018). This is reinforced by the input of nutrients from the region's extensive mangrove forests (Dittmar and Lara, 2001), which also determines its high phytoplankton biomass (reflected in the chlorophyll $a$ concentrations). Oscillations in these variables are controlled primarily by the local meso-macrotides and rainfall levels, with high values being reached during the rainy season (contribution of rivers), and equinoctial spring tides (re-suspension of fine material and benthic photosynthetic species into the water column). Although these high nutrient concentrations may be affected by the discharge of sewage, as occurred in Ajuruteua (see section 4.2), new limits should be considered by CONAMA for this region as previously proposed by Sousa et al. (2017).

\subsection{Anthropogenic conditions}

In section 4.1 it is showed when and why sandy Amazon beaches are overcrowded, but what are the consequences of overcrowd in protect areas such as these located within studied RESEX's? Overcrowding can reduce the quality of the recreational experience on a beach and may be responsible for the onset of environmental problems (Jurado et al., 2013). Ideally, at least $10 \mathrm{~m}^{2}$ should be available to each beachgoer on semi-urban beaches and $12 \mathrm{~m}^{2}$ on rural beaches (Sousa et al., 2017), but values of less than $2 \mathrm{~m}^{2} /$ visitor were recorded in the backshore sector (bars and restaurants) and the surf zone during school vacations. How can overcrowding and the lack of regulatory measures influence the quality of beaches and the way of life of the traditional community located within Resex areas?

Firstly, the facilities available on these beaches are scarce, absent or unsatisfactory for local residents and beachgoers alike. Scarcity of facilities is common on rural beaches, but the absence or 
the presence of unsatisfactory basic services, such as basic sanitation is unacceptable. As example, no wastewater treatment plants are available anywhere on the Amazon coast, and recreational activities can be affected by the presence of cesspits or illegal sewage outfalls in the mangrove or intertidal zone, and on dunes (Pinto et al., 2011; Silva et al., 2013; Sousa et al., 2016). The discharge of sewage into coastal waters is banned in most parts of the world, due to the risks to human health, in particular that of bathers (Chen, 2015). The water of Amazonian beaches is contaminated by bacteria primarily during high spring tides, in particular during the vacation period, when the number of beachgoers peaks (Pinto et al., 2011; Sousa et al., 2016). Thermotolerant coliforms are indicators of the lack of efficient sanitation systems. One of the bacteria in this group, Escherichia coli, is found only in the human intestine, and is widely considered to be a reliable indicator of the contamination of beach water by sewage, with enormous risks for public health (Wade et al., 2010; Azis et al., 2017). At Pesqueiro beach, however, the water was not contaminated by thermotolerant coliforms because cesspits are prohibited in the intertidal zone. At Ajuruteua, by contrast, cesspits contribute to the contamination of the water, and thermotolerant coliform concentrations exceeded the CONAMA threshold during the school vacation period and dry season public holidays, when the numbers of beachgoers peak (Oliveira et al., 2011; Pessoa et al., 2016). Norat-Ramirez et al. (2019) showed that high levels of contamination also are found in marine reserves in Puerto Rico. In addition to bacteriological contamination, sewage causes visual pollution and unpleasant odors.

Solid waste, such as glass, paper, metal and plastic containers, food, and discarded building materials, is an additional environmental problem. While beaches are used primarily for leisure activities, intended to increase human wellbeing, the degradation of the natural scenery by the presence of garbage may also have an impact on recreational activities. On the beaches where motor vehicles are permitted, waste is disposed of in bins or plastic bags distributed across the intertidal zone, which must be collected before high tide. Where vehicles are banned, however, bar owners are responsible for the collection and disposal of the waste produced by their customers and thereafter leave them to a waste container. In both cases, part of the waste is often overlooked, and is then 
transported by tidal currents to other beaches, mangroves or dune fields. Similar problems were identified in previous studies of Amazonian beaches (Pereira et al., 2018), and are the result of the lack of adequate recipients and the intermittent collection of waste.

Garbage may also attracts insects and rats, with the potential for the transmission of diseases, and may contain materials, such as broken glass, that can cause injuries (Araújo and Costa, 2006; Ariza et al., 2008). These problems have been already identified in previous studies of Amazonian beaches (both oceanic and estuarine) and are related to the lack of adequate waste recipients and the intermittent collection of waste (Pereira et al., 2007; Sousa et al., 2017). In most cases, municipalities have inadequate solid waste management procedures, and many Amazonian beaches, such as Ajuruteua, tend to be inundated by garbage during peak visitation periods, even when covered by the Clean Beach Project, which is supported by both state and municipal offices (e.g., environment and tourism), and federal universities.

The presence of domestic animals, such as dogs and horses, on the beaches, may also cause health problems. Stray dogs are found on many Amazonian beaches (including Ajuruteua and Pesqueiro), increasing the risk of exposure to zoonotic diseases - such as scabies, ringworm, toxoplasmosis, and other types of parasite (Cleaveland et al., 2001). Donkeys and buffaloes, which are used as tourist attractions (donkey carts on Princesa beach and buffalo rides at Pesqueiro) may also transmit diseases to humans, although no cases have been registered in beachgoers.

Marine erosive processes may cause the destruction of buildings and the degradation of natural environments, such as beaches, dunes or mangroves, due to either natural processes, such as wind, rain, tides, and waves, or human activities, like unregulated land use (Scherer, 2013). As a consequence, a number of both natural and socioeconomic impacts may arise, including the loss of recreational potential. These processes may require the implementation of either hard (seawalls, groins and breakwaters) or soft (artificial nourishment, restoration of dunes and mangroves) measures to contain erosion and protect specific features of the coastline (Masria et al., 2015). The occupation of land on the Amazon coast is regulated by federal, state, and municipal laws. Despite this, the 
construction of buildings in the mangrove and intertidal zone, and on dunes, have contributed to the intensification of erosive processes, leading to the need to construct seawalls (made of rock, wood, concrete or sandbags) to offset the destruction of private beachside properties or the degradation of natural environments, as observed commonly on Ajuruteua beach. Unfortunately, the seawalls constructed at Ajuruteua are not designed to withstand extreme natural events, and they are often partially destroyed during equinoctial periods (Oliveira et al., 2011; Pereira et al., 2014). At Pesqueiro beach, ICMBio monitors land use, and when natural erosive processes affect established buildings, they are relocated to a more secure area. Other measures may include the relocation of local inhabitants (Ingram et al., 2006), although resettlement costs are very high, in particular for the poorest families on the Amazon coast (Pereira et al., 2007; Szlafsztein, 2012).

\section{FINAL CONSIDERATIONS}

Our findings indicate that recreational activities are under control on Pesqueiro beach, and that the Soure Marine Extractive Reserve supports the development of sustainable local tourism. At Ajuruteua beach, however, Caeté-Taperaçu Marine Extractive Reserve does not provide adequate regulation of local recreational activities, given that numerous conflicts arising from the economic interests related to tourism. The lack of any effective municipal management initiatives and the absence of adequate communication between local residents, visitors, the owners of local establishments, the scientific community, and local authorities, have generated a series of environmental and social problems in that beach, despite the establishment of the Municipal Coastal Management Working Group. Thus, Ajuruteua does not provide adequate support for recreational activities and the elaboration of the Caeté-Taperaçu RESEX management plan must include regulate recreational aspects that will be increasingly frequent and intense. The inclusion of traditional populations has been a major theme of the creation of FCUs on the coast of the state of Pará, but unfortunately subsistence practices have been losing place to recreational activities in Ajuruteua beach, where a source of income from these activities is guaranteed only in peak periods. In this case, 
regulation is extremely necessary to guarantee the protection of the local environment and the sociocultural sustainability of traditional local communities, in addition to the satisfaction of local beachgoers. For end, our results suggest that the creation of RESEXs can be considered an adequate approach to control recreational activities in the amazon littoral. In Pesqueiro beach, for example, management tools towards the regulation of recreational activities in these protection units showed to be compatible with its sustainable use.

\section{ACKNOWLEDGEMENTS}

This study was financed by $\mathrm{CNPq}$, through a Universal project (483913/2012-0), and by CAPES (Ciências do Mar II, Edital 43/2013, and Pró-Amazônia). The author Pessoa RMC is grateful to CAPES for research grants (Finance Code 001). Pereira LCC (310909/2014-7) and Costa RM (309527/2014-7 and 311782/2017-5) would also like to thank CNPq for research grants. Thanks to the Brazilian Ministry of the Environment (MMA) and Chico Mendes Institute for Biodiversity Conservation (ICMBio) for allow the development of this study (Num.50851-1) within the RESEX areas. We are also indebted to Stephen Ferrari for his careful revision of the English text.

\section{REFERENCES}

Almeida, A.F., Gon, M.A., 2018. Mudanças socioeconômicas e ambientais resultantes das políticas públicas de desenvolvimento socioeconômico no litoral do Nordeste do Pará, Brasil 49, 108-129. https://doi.org/10.5380/dma.v49i0.55128.

APHA - American Public Health Association, 2004. Standard methods for examination of water and wastewater. Washington, D.C. http://www.standard.methods.org/Articles.cfm/ (accessed 15 May 2016).

Araújo, M.C.B., Costa, M.F., 2006. Visual diagnosis of solid waste contamination of a tourist beach: Pernambuco, Brazil. Waste Manage. 27 (6), 833-839. https://doi.org/10.1016/j.wasman.2006.04.018. 
Araújo, M.C.B., Costa, M.F., 2008. Environmental quality indicators for recreational beaches classification. J. Coast. Res. 246, 1439-1449. https://doi.org/10.2112/06-0901.1.

Ariza, E., Jiménez, J.A., Sardá, R., 2008. Seasonal evolution of beach waste and litter during the bathing season on the Catalan coast. Waste Manage. 28 (12), 2604-2613. https://doi.org/10.1016/j.wasman.2007.11.012.

Azis, P.A., Mancera-Pineda, J.E., Gavio, B., 2017. Rapid assessment of coastal water quality for recreational purposes: methodological proposal. Ocean Coast. Manage. 151 (1), 118-126. https://doi.org/10.1016/j.ocecoaman.2017.10.014.

Bentes, B., Isaac, V.J., Espírito-Santo, R.V., Fredou, T., Almeida, M.C., Mourão, K.R.M., Fredou, F.L., 2012. Multidisciplinary approach to identification of fishery production systems on the northern coast of Brazil. Biota Neotrop. 12, 81-92. https://doi.org/10.1590/S1676-06032012000100006.

Brasil, 2001. Decreto de 22 de novembro de 2001. Cria a Reserva Extrativista Marinha de Soure, no município de Soure, Estado do Pará, e dá outras providencias. Casa Civil: Subchefia para Assuntos Jurídicos, Brasília-DF.

Brasil, 2005. Decreto de 20 de maio de 2005. Dispõe sobre a criação da Reserva Extrativista Marinha de Caeté-Taperacú, no município de Bragança, no Estado do Pará, e dá outras providencias. Senado Federal, Brasília-DF.

Chen, C.L., 2015. Regulation and management of marine litter, in: Bergmann, M., Gutow, L., Klages, M. (Eds.), Marine Anthropogenic Litter. Springer Open, Bremerhaven, pp. 399-432.

Cleaveland, S., Laurenson, M.K., Taylor, L.H., 2001. Diseases of humans and their domestic mammals: pathogen characteristics, host range and the risk of emergence. Phil. Trans. R. Soc. Lond. B. 356, 991-999. https://doi.org/10.1098/rstb.2001.0889.

Coccossis, H., Mexa, A., 2004. The challenge of tourism carrying capacity assessment: Theory and practice. Ashgate Publishing, Aldershot. 
CONAMA - Conselho Nacional de Meio Ambiente, 2000. Resolução nº 27429 de novembro de 2000. Define os critérios de balneabilidade em águas brasileiras. http://www.mma.gov.br/port/CONAMA/legiabre.cfm?codlegi=272 (accessed 15 April 2018).

CONAMA - Conselho Nacional de Meio Ambiente, 2005. Resolução n 357, de 17 de março de 2005. Dispõe sore a classificação dos corpos de água e diretrizes ambientais para o seu enquadramento, bem como estabelece as condições e padrões de lançamento de efluentes, e dá outras providencias. http://pnqa.ana.gov.br/Publicacao/RESOLUCAO_CONAMA_n_357.pdf (accessed 06 February 2018).

Costa, K.G., Bezerra, T.R., Monteiro, M.C., Vallinoto, M.N., Berredo, J.F., Pereira, L.C.C., Costa, R.M., 2013. Tidal-induced changes in the zooplankton community of an Amazon estuary. J. Coast. Res. 29 (4), 756-765. https://doi.org/10.2112/JCOASTRES-D-11-00166.1.

Dittmar, T., Lara, R.J., 2001. Driving forces behind nutrient and organic matter dynamics in a mangrove tidal creek in North Brazil. Estuar. Coast. Shelf Sci. 52 (2), 249-259. https://doi.org/10.1006/ecss.2000.0743.

Eugênio-Martin, J.L., 2004. Monitoring the congestion level of competitive destinations with mixed logic models. University of Nottingham Wollaton Road, Nottingham, NG8 1BB, UK. http://www.nottingham.ac.uk.

França, C.F., Souza Filho, P.W.M., 2003. Análise das mudanças morfológicas costeiras de médio período na margem leste da ilha de Marajó (PA) em Imagem Landsat. Rev. Bras. Geociencias. 33 (2), 127-136.

Gavio, B., Palmer-Cantillo, S., Mancera, J.E., 2010. Historical analysis (2000 e 2005) of the coastal water quality in San Andres Island, Sea Flower Biosphere Reserve, Caribbean Colombia. Mar. Pollut. Bull. 60 (7), 1018-1030. https://doi.org/10.1016/j.marpolbul.2010.01.025.

Grasshoff, K., E.M. Rhardt, M., Kremling, K., 1999. Methods of Seawater Analysis. 3rd edition, Weinheim; New York, Wiley-VCH. 
Grasshoff, K., Emrhardt, M., Kremling, E.K., 1983. Methods of seawater analysis. Verlag Chemie, New York.

IBGE - Instituto Brasileiro de Geografia e Estatística, 2018. Sinopse do censo demográfico 2010: Pará. https://censo2010.ibge.gov.br/sinopse/index.php?dados=0\&uf=15/ (accessed 22 March 2018). ICMBIO - Instituto Chico Mendes da Biodiversidade, 2012. Plano de Manejo da Reserva Extrativista Marinha de Caeté-Taperacú (PA): Diagnóstico. ICMBio, Brasília-DF.

Ingram, J.C., Franco, G., Rio, C.R., Khazai, B., 2006. Post-disaster recovery dilemmas: challenges in balancing short-term and long-term needs for vulnerability reduction. Environ. Sci. Policy. 9 (7-8), 607-613. https://doi.org/10.1016/j.envsci.2006.07.006.

INMET - Instituto Nacional de Meteorologia, 2018. Estações automáticas: estação meteorológica de observação de superfície automática. http://www.inmet.gov.br/portal/index.php?r=estacoes/estacoesautomaticas/ (accessed 19 June 2016). Jiménez, J.A., Osorio, A., Marino-Tapia, I., Davidson, M., Medina, R., Kroon, A., Archetti, R., Ciavola, P., Aarnikhof, S.G.J., 2007. Beach recreation planning using video-derived coastal state indicators. Coast. Eng. 54, 507-521. https://doi.org/10.1016/j.coastaleng.2007.01.012.

Jurado, E.N., Damian, I.M., Morales, A.F., 2013. Carrying capacity model applied in coastal destinations. Ann. Tour. Res. 43, 1-19. https://doi.org/10.1016/j.annals.2013.03.005.

Lobato, G.D.J.M., Martins, A.C.C.T., Lucas, F.C.A., Morales, G.P., Rocha, T.T., 2014. Reserva Extrativista Marinha de Soure, Pará, Brasil: modo de vida das comunidades e ameaças ambientais. Bioata Amaz. 4 (4), 66-74. http://dx.doi.org/10.18561/2179-5746/biotaamazonia.v4n4p66-74.

Lucrezi, S., Milanese, M., Markantonatou, V., Cerrano, C., Sarà, A., Palma, M., Saayman, M., 2017. Scuba diving tourism systems and sustainability: Perceptions by the scuba diving industry in two Marine Protected Areas. Tour. Manage. 59, 385-403. https://doi.org/10.1016/j.tourman.2016.09.004. Masria, A., Iskander, M., Negm, A., 2015. Coastal protection measures, case study (Mediterranean zone, Egypt). J. Coast. Conserv. 19 (3), 281-294. https://doi.org/10.1007/s11852-015-0389-5. 
MITUR - Ministério do Turismo, 2010. Turismo de sol e praia: Orientações básicas. 2. ed. Brasília: Ministério do Turismo.

Moraes, B.C., Costa, J.M.N., Costa, A.C.L., Costa, M.H., 2005. Variação espacial e temporal da precipitação no estado do Pará. Acta Amaz. 35 (2), 207-214. http://dx.doi.org/10.1590/S004459672005000200010.

Moreira, A.M., Silva, K.L., 2012. Reserva Extrativistas do litoral paraense: ferramentas para o ordenamento territorial, in: III Congresso Brasileiro de Gestão Ambiental. Goiânia-GO, pp. 1-6.

Norat-Ramirez, J. Mendez-Lazaro, P. Hernandez-Delgado, E.A., Mattei-Torres, H., Cordero-Rivera, L., 2019. A septic waste index model to measure the impact of septic tanks on coastal water quality and coral reef communities in Rincon, Puerto Rico. Ocean Coast. Manage. 169, 201-213. https://doi.org/10.1016/j.ocecoaman.2018.12.016.

Oliveira, S.M.O., Pereira, L.C.C., Vila-concejo, A., Gorayeb, A., Sousa, R.C., Souza Filho, P.W.M., Costa, R.M., 2011. Natural and anthropogenic impacts on a macrotidal sandy beach of the Brazilian Amazon (Ajuruteua, Pará): guidelines for coastal management. J. Coast. Res. SI 64, 1385-1389.

Parsons, T.R., Strickland, J.D.H., 1963. Discussion of spectrophotometric determination of marine plankton pigments, with revised equations of ascertaining Chlorophyll-a and carotenoids. J. Mar. Res., 21 (3), 155-163.

Pereira, L.C.C., Guimarães, D.O., Ribeiro, M.J.S., Costa, R.M., Souza Filho, P.W.M., 2007. Use and occupation in Bragança littoral, Brazilian Amazon. J. Coast. Res. SI 50, 1116-1120.

Pereira, L.C.C., Mendes, C.M., Monteiro, M.C., Asp, N.E., 2009. Morphological and sediment logical changes in a macrotidal sand beach in the Amazon Littoral (Vila Dos Pescadores, Pará, Brazil). J. Coast. Res. SI 56, 113-117. https://www.jstor.org/stable/25737548.

Pereira, L.C.C., Oliveira, S.M.O., Costa, R.M., Costa, K.G., Vila-Concejo, A., 2013. What happens on an equatorial beach on the Amazon coast when La Niña occurs during the rainy season? Estuar. Coast. Shelf Sci. 135, 116-127. https://doi.org/10.1016/j.ecss.2013.07.017. 
Pereira, L.C.C., Sousa, R.C., Costa, R.M., Jiménez, J.A., 2018. Challenges of the recreational use of Amazon beaches. Ocean Coast. Manage. 165, 52-62. https://doi.org/10.1016/j.ocecoaman.2018.08.012.

Pereira, L.C.C., Vila-Concejo, A., Costa, R.M., Short, A.D., 2014. Managing physical and anthropogenic hazards on macrotidal Amazon beaches. Ocean Coast. Manage. 96, 149-162. https://doi.org/10.1016/j.ocecoaman.2014.05.008.

Pereira, L.C.C., Vila-Concejo, A., Short, A.D., 2016. Coastal morphodynamic processes on the macro-tidal beaches of Pará state under tidally-modulated wave conditions, in: Short, A.D., Klein, A.H.F. (Org.). Brazilian beach systems. Springer, Switzerland, pp.95-124. https://doi.org/10.1007/978-3-319-30394-9_4.

Pessoa, R.M.C., Pereira, L.C.C., Sousa, R.C., Costa, R.M., 2016. Water quality during the recreational high season for a macrotidal beach (Ajuruteua, Pará, Brazil). J. Coast. Res. SI 75, 12221226. https://doi.org/10.2112/SI75-245.1.

Pessoa, R.M.C., Pereira, L.C.C., Sousa, R.C., Magalhães, A., Costa, R.M., 2013. Recreational carrying capacity of an Amazon macrotidal beach during vacation periods. J. Coast. Res. SI 65, 10271032. https://doi.org/10.2112/SI65-174.1

Pinto, K.S.T., Pereira, L.C.C., Gorayeb, A., Sousa, R.C., Costa, R.M., 2011. Effects of the lack of coastal planning on water quality and land use on a macrotidal beach (Atalaia, Pará) in the Amazon Region. J. Coast. Res. SI 64, 1401-1405.

Rodrigues, T.W.P., Szlafsztein, C., 2011. Análise multi-temporal da cobertura da terra antes e depois da criação da Resex Marinha de Soure-PA. In Anais XV Simpósio Brasileiro de Sensoriamento Remoto - SBSR, Curitiba, PR, Brasil, 30 de abril a 05 de maio de 2011, INPE 1989-1996.

Ruschmann, D., 1999. Turismo e Planejamento Sustentável: A Proteção do Meio Ambiente. Papirus, Campinas-SP.

Scherer, M., 2013. Beach Management in Brazil: Topics for Consideration. Rev. da Gestão Costeira Integr. 13 (1), 3-13. https://doi.org/10.5894/rgci358. 
Silva, I.R., Pereira, L.C.C., Trindade, W.N., Magalhães, A., Costa, R.M., 2013. Natural and anthropogenic processes on the recreational activities in urban Amazon beaches. Ocean Coast. Manage. 76, 75-84.http://dx.doi.org/10.1016/j.ocecoaman.2012.12.016.

Silva, N.I.S., Pereira, L.C.C., Gorayeb, A., Vila-Concejo, A., Sousa, R.C., Asp, N.E., Costa, R.M., 2011. Natural and social conditions of Princesa, a macrotidal sandy beach on the Amazon Coast of Brazil. J. Coast. Res. SI 64, 1979-1983.

Sousa, R.C., Pereira, L.C.C., Costa, R.M., Jiménez, J.A., 2017. Management of estuarine beaches on the Amazon coast though the application of recreational carrying capacity indices. Tour. Manage. 59, 216-225. https://doi.org/10.1016/j.tourman.2016.07.006.

Sousa, R.C., Pereira, L.C.C., Jiménez, J.A., 2016. Estuarine Beaches of the Amazon coast: environmental and recreational characterization. J. Coast. Res. SI 75, 705-709. https://doi.org/10.2112/SI75-141.1.

Sousa, R.C., Pereira, L.C.C., Silva, N.I.S., Oliveira, S.M.O., Pinto, K.S.T., Costa, R.M., 2011. Recreational carrying capacity of three Amazon macrotidal beaches during the peak vacation season. J. Coast. Res. SI 64, 1292-1296.

Souza Filho, P.W.M., Gonçalves, F.D., Beisl, C.H., Miranda, F.P., Almeida, E.F., Cunha, E.R., 2005. Coastal observing system and the role of the remote sensors in the Northern Brazilian coast monitoring, Amazon. Rev. Bras. Cartogr. 57, 79-86.

Souza, P.C., 2008. Turismo Sustentável: um estudo prospectivo no município de Soure - Ilha do Marajó - PA. Universidade de Brasília, Brasília-DF.

Strickland, J.D., Parsons, T.R.A., 1972. A practical handbook of seawater analysis (2th ed). J. Fish. Res. Board Can. Ott. 167, 207-211.

Szlafsztein, C.F, Sterr, H., 2007. A GIS-based vulnerability assessment of coastal natural hazards, State of Pará, Brazil. J. Coast. Conserv. 11, 53-66. https://doi.org/10.1007/s11852-007-0003-6. Szlafsztein, C.F., 2009. Non-Definition and Obstacles in the Coastal Zone Management of the state of Pará, Brazil. Rev. da Gestão Costeira Integr. 9 (2), 47-58. https://doi.org/10.5894/rgci114. 
Szlafsztein, C.F., 2012. Natural disasters management in the Brazilian Amazon: an analysis of the states of Acre, Amazonas and Pará. In: Cheval, Sorin (Ed.), Natural Disasters. INTECH, Zagreb. https://www.intechopen.com/books/natural-disasters/natural-disasters-management-in-thebrazilian-amazon-an-analysis-of-the-states-of-acre-amazonas-and-.

UNESCO - United Nations Educational, Scientific and Cultural Organization, 1966. Determination of Photosynthetic Pigments in Sea-water. Unesco, Paris.

Wade, T.J., Sams, E., Brenner, K.P., Haugland, R., Chern, E., Beach, M., Wymer, L., Rankin, C.C., Love, D., Li, Q., Noble, R., Dufour, A.P., 2010. Rapidly measured indicators of recreational water quality and swimming-associated illness at marine beaches: a prospective cohort study. Environ. Heal. 9 (66), 2-14. https://doi.org/10.1186/1476-069X-9-66.

Zolfani, S.H., Sedaghat, M., Maknoon, R., Zavaskas, E.K., 2015. Sustainable tourism: a comprehensive literature review on frameworks and applications. Econ Res-Ekon Istraz. 28 (1), 130. https://doi.org/10.1080/1331677X.2014.995895. 


\section{FIGURE CAPTIONS}

Figure 1: A) Location of Pesqueiro and Ajuruteua beaches in the coastal zone of Pará, northern Brazil;

B) Outline of the Soure Marine Extractive Reserve; C) Outline of the Caeté-Taperaçu Marine Extractive Reserve; D) Pesqueiro and E) Ajuruteua beaches detaching the studied transects in Z1 (backshore), Z2 (intertidal zone), Z3 (surf zone).

Figure 2. Rainfall level $(\mathrm{mm})$ and air temperature $\left({ }^{\circ} \mathrm{C}\right)$ recorded in the study area. The arrows are highlighting the studied period and the gray hatching represents the rainy season.

Figure 3. Spatial and temporal variation in visitation rates and the Recreational Carrying Capacity (RCC) at the study beaches, highlighting the number of visitors in each of the three beach zones at Ajuruteua (A) and Pesqueiro (B) beaches, the number of visitors per hour in the vacation period at Ajuruteua (C) and Pesqueiro (D) and the Recreational Carrying Capacity of zone 1 on Sunday at Ajuruteua (E) and Pesqueiro (F).

Figure 4. (A) Erosion problem due to unregulated occupation of intertidal zone in Ajuruteua beach; (B) Seawalls being built to control the erosion in Ajuruteua beach; (C) Natural erosion on mangrove area in Pesqueiro beach; (D) Absence of wheelchair access ramp in Ajuruteua beach.

Figure 5. (A) Cesspit being flooded by the tide (Ajuruteua); (B) Solid waste within the intertidal zone (Ajuruteua); C) Presence of buffalo in Pesqueiro beach; D) Banana boats navigating within bathing area (Ajuruteua). 

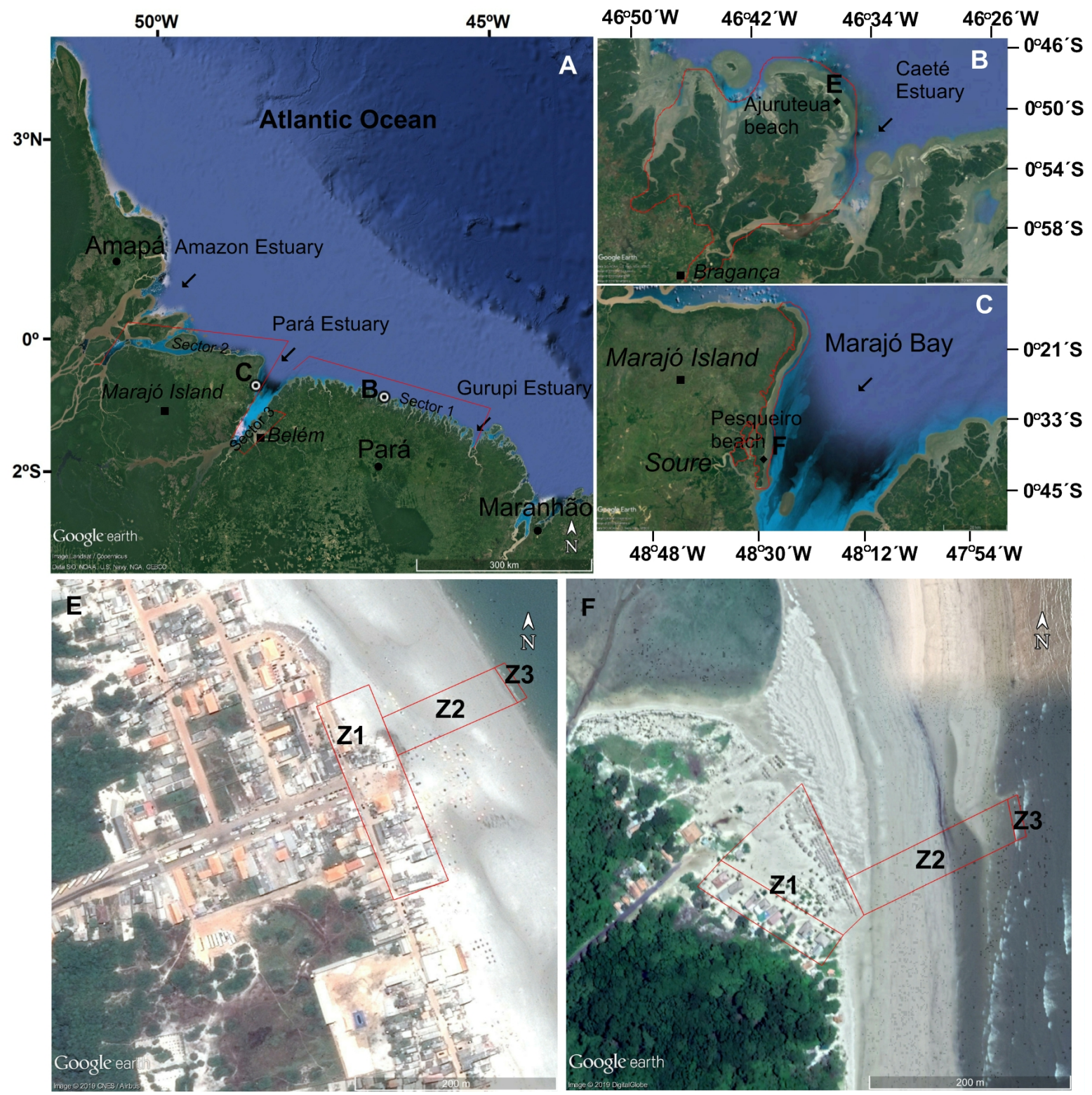


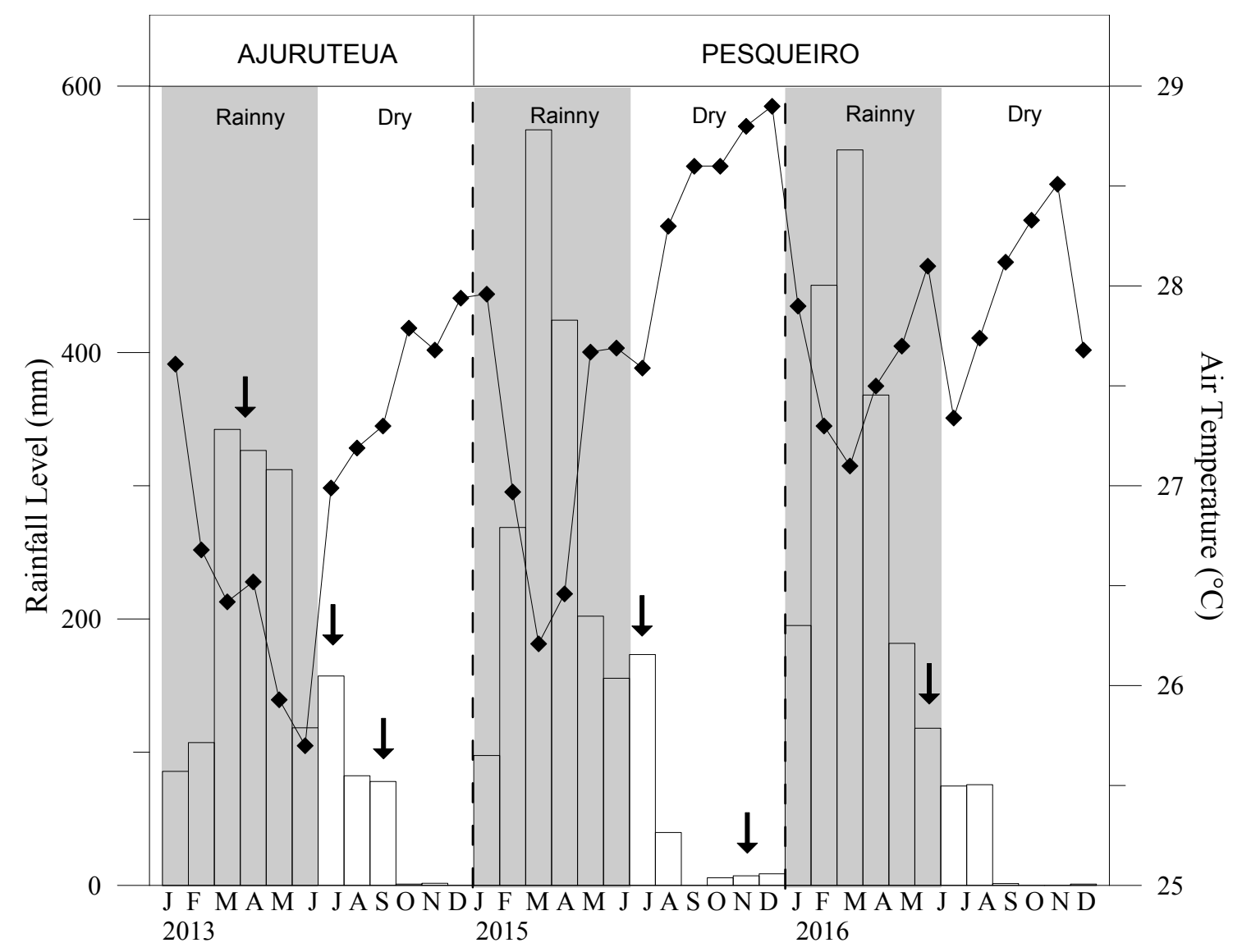

Figure 2. 

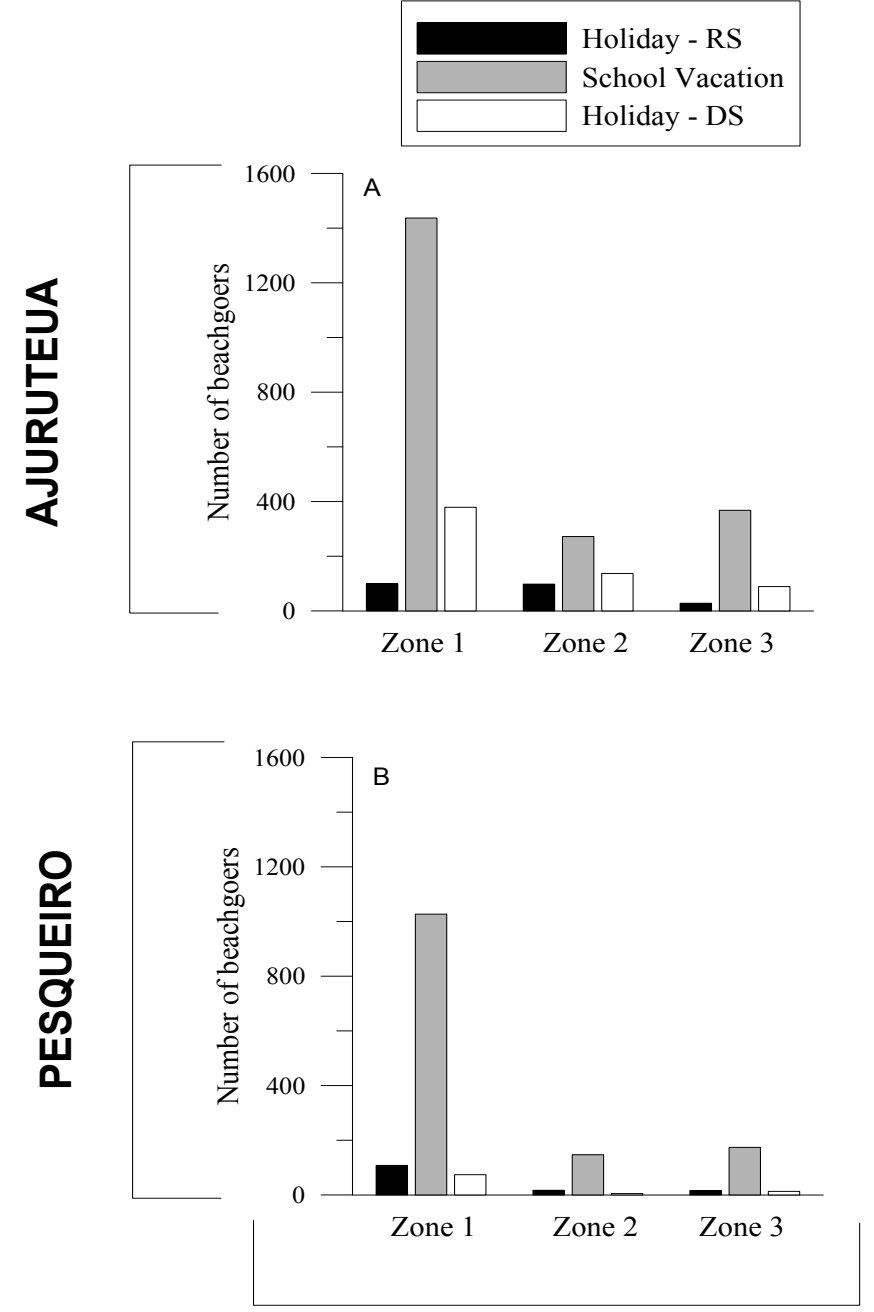

Spatial/Zone
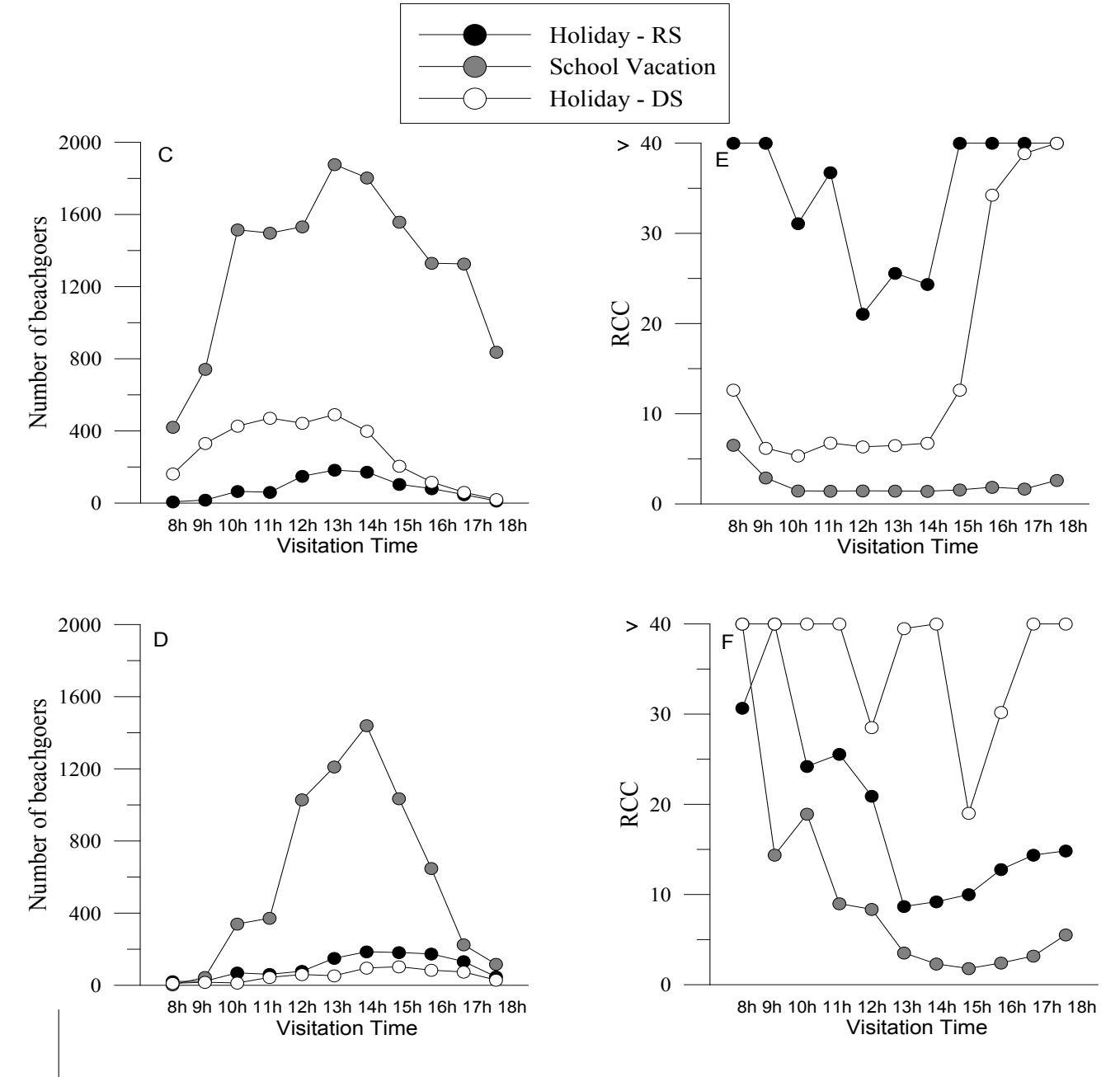

Temporal/Hour

Figure 3. 


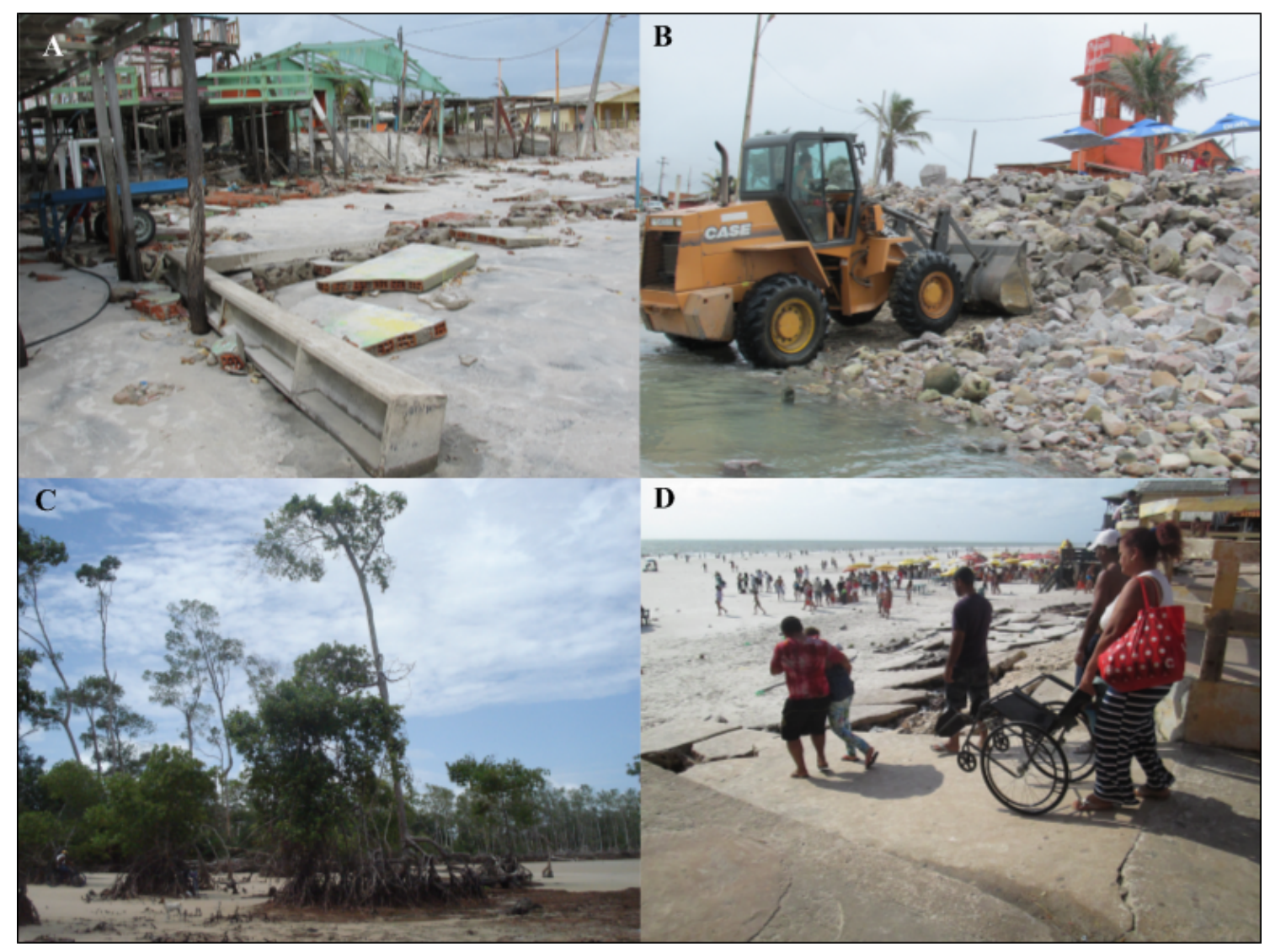

Figure 4. 


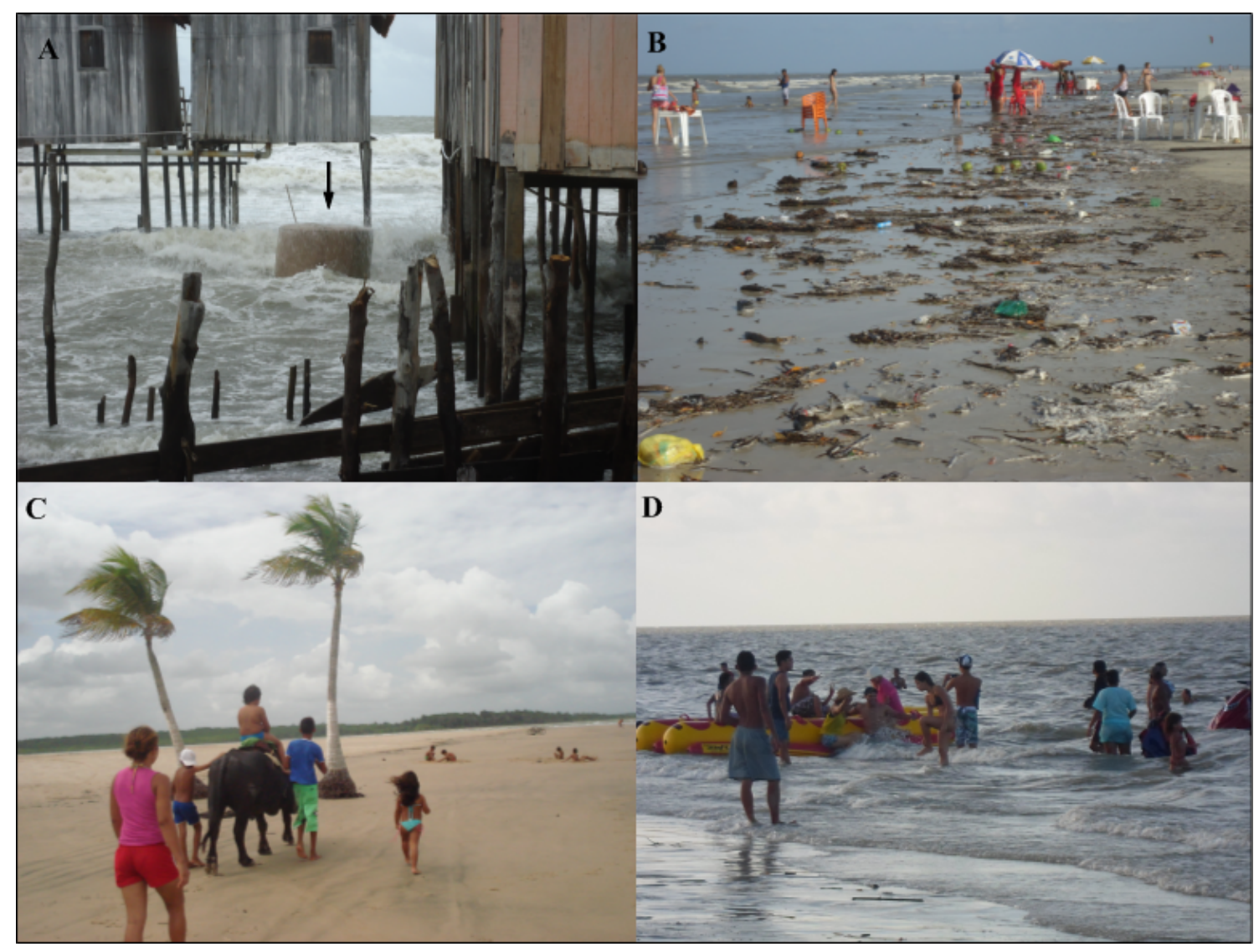

Figure 5. 
Table 1. Federal Conservation Units: categories, competences and federal unit types.

Details to Extractive Reserve.

\begin{tabular}{|c|c|c|}
\hline CATEGORIES & COMPETENCE & UNITS $^{1}$ \\
\hline $\begin{array}{l}\text { Fully protected } \\
\text { units }\end{array}$ & $\begin{array}{l}\text { To maintain the natural } \\
\text { ecosystem without anthropic } \\
\text { interference. }\end{array}$ & $\begin{array}{l}\text { - National Park } \\
\text { - Biological Reserve } \\
\text { - Ecological State } \\
\text { - Natural Monuments } \\
\text { - Wildlife Refuges }\end{array}$ \\
\hline $\begin{array}{c}\text { Sustainable use } \\
\text { units }\end{array}$ & $\begin{array}{l}\text { To allow sustained use of } \\
\text { renewable environmental } \\
\text { resources, maintaining } \\
\text { biodiversity and other } \\
\text { ecological attributes. }\end{array}$ & $\begin{array}{l}\text { - Extractive reserves } \\
\text { - Areas of Relevant Ecological } \\
\text { Interest } \\
\text { - Environmental Protection } \\
\text { Areas } \\
\text { - National Forest } \\
\text { - Wildlife Reserves } \\
\text { - Sustainable Development } \\
\text { Reserves } \\
\text {-Private Natural Heritage } \\
\text { Reserves }\end{array}$ \\
\hline
\end{tabular}

${ }^{1}$ Administrated by the Chico Mendes Institute for Biodiversity Conservation.

${ }^{2}$ Extractive reserve is a protection figure, where the land is public domain, but traditional extractive practices are allowed (e.g. fishing, hunting and harvesting wild plants) for local communities. Extractive reserves were also created to protect livelihoods and culture of the local inhabitants. Public visits are allowed when compatible with local interests and the provisions of the management plan for the unit. Research is permitted and encouraged, subject to prior authorization with the responsible agency. 
Table 2. Details of the field campaigns conducted during the study period.

\begin{tabular}{|c|c|c|c|c|c|c|}
\hline Local & $\begin{array}{l}\text { Climatic } \\
\text { conditions }\end{array}$ & Recreational period & Type & Date & Tide & Time \\
\hline \multirow{4}{*}{ Ajuruteua } & Rainy season & $\begin{array}{l}\text { Public Holiday } \\
\text { weekend }\end{array}$ & Easter weekend & $\begin{array}{l}03 / 29- \\
04 / 01 / 2013\end{array}$ & $\begin{array}{l}\text { Spring tide } \\
\text { of } \\
\text { equinoctial } \\
\text { period }\end{array}$ & $96 \mathrm{~h}$ \\
\hline & $\begin{array}{l}\text { Transitional } \\
\text { period }\end{array}$ & School vacation & First weekend & $07 / 05-08 / 2013$ & Spring tide & $96 \mathrm{~h}$ \\
\hline & $\begin{array}{l}\text { Transitional } \\
\text { period }\end{array}$ & School vacation & Last weekend & $07 / 27-28 / 2013$ & $\begin{array}{l}\text { Spring to } \\
\text { neap tide }\end{array}$ & $48 \mathrm{~h}$ \\
\hline & Dry season & $\begin{array}{l}\text { Public Holiday } \\
\text { weekend }\end{array}$ & $\begin{array}{l}\text { Independence } \\
\text { Day }\end{array}$ & $09 / 07-08 / 2013$ & $\begin{array}{l}\text { Spring tide } \\
\text { of } \\
\text { equinoctial } \\
\text { period }\end{array}$ & $48 \mathrm{~h}$ \\
\hline \multirow{3}{*}{ Pesqueiro } & Rainy season & $\begin{array}{l}\text { Public Holiday } \\
\text { weekend }\end{array}$ & Valentine's day & $06 / 12 / 2016$ & Neap tide & $24 \mathrm{~h}$ \\
\hline & $\begin{array}{l}\text { Transitional } \\
\text { period }\end{array}$ & School vacation & School vacation & $07 / 26 / 2015$ & Neap tide & $24 \mathrm{~h}$ \\
\hline & Dry season & $\begin{array}{l}\text { Public Holiday } \\
\text { weekend }\end{array}$ & Círio de Nazaré & $11 / 08 / 2015$ & Neap tide & $24 \mathrm{~h}$ \\
\hline
\end{tabular}


Table 3. Hydrological variables recorded during the present study at Pesqueiro and Ajuruteua beaches (*: No data; **: No reference value; RS:

Rainy season; DS: Dry season). Bold text highlights the recorded values above the limits or thresholds.

\begin{tabular}{|c|c|c|c|c|c|c|c|c|}
\hline \multirow[b]{2}{*}{ Variables } & \multicolumn{3}{|c|}{ AJURUTEUA } & \multicolumn{3}{|c|}{ PESQUEIRO } & \multicolumn{2}{|c|}{ CONAMA limits } \\
\hline & Holiday (RS) & School vacation & Holiday (DS) & Holiday (RS) & School vacation & Holiday (DS) & Brackish water & Saline Water \\
\hline Salinity (\%o) & 21.3 to 25.7 & 30.8 to 33.3 & $*$ & 2.1 to 2.7 & 5.5 to 6.5 & 9.3 to 9.9 & $>0.5$ to $<30$ & $\geq 30$ \\
\hline $\mathrm{pH}$ & 7.5 to 7.9 & 7.6 to 8.5 & 7.9 to 8.3 & 6.9 to 7.4 & 8.0 to 8.3 & 8.1 to 8.6 & 6.5 to 8.5 & 6.5 to 8.5 \\
\hline Turbidity (NTU) & 27.5 to 957.9 & 3.8 to 748.7 & $*$ & 45.82 to 701.5 & 5.5 to 449.3 & 7.4 to 120.7 & Absence & Absence \\
\hline Temperature $\left({ }^{\circ} \mathrm{C}\right)$ & 27.7 to 33.1 & 26.8 to 30.4 & $*$ & 25.8 to 30.4 & 28.4 to 30.2 & 28.1 to 30.3 & $* *$ & $* *$ \\
\hline Nitrite (mg/L) & 0.0006 to $\mathbf{0 . 1 2 7 7}$ & 0.0006 to 0.0068 & 0.0024 to 0.0050 & 0.0074 to 0.0150 & 0.0008 to 0.0022 & 0.0002 to 0.0014 & $<0.07$ & $<0.07$ \\
\hline Nitrate (mg/L) & 0.1164 to $\mathbf{3 . 4 2 2 4}$ & 0.1256 to 0.1796 & 0.1445 to 0.2769 & 0.0021 to 0.3252 & 0.0378 to 0.1144 & 0.0027 to 0.1683 & $<0.40$ & $<0.40$ \\
\hline Phosphate (mg/L) & 0.0094 to 0.0922 & 0.0013 to 0.1368 & 0.0282 to 0.1562 & 0.0096 to 0.0436 & 0.0206 to 0.0230 & 0.0065 to 0.0083 & $* *$ & $* *$ \\
\hline $\begin{array}{l}\text { Total phosphorus } \\
(\mathrm{mg} / \mathrm{L})\end{array}$ & 0.0183 to $\mathbf{0 . 1 3 6 0}$ & 0.0282 to $\mathbf{0 . 1 4 6 3}$ & 0.0380 to $\mathbf{0 . 2 3 8 9}$ & 0.0165 to 0.0610 & 0.0055 to 0.0248 & 0.0078 to 0.0193 & $<0.124$ & $<0.062$ \\
\hline Chlorophyll $a(\mathrm{~g} / \mathrm{L})$ & 0.64 to 26.49 & 2.96 to 28.61 & 3.00 to 17.38 & 33.47 to 72.98 & 3.84 to 15.17 & 0.63 to 5.86 & $* *$ & $* *$ \\
\hline
\end{tabular}


Table 4. Thermotolerant coliform (maximal permitted number per $100 \mathrm{ml}$ ) classified according with CONAMA standards for waters destined for recreation use by primary contact (RS - Rainy season, DS - Dry season).

\begin{tabular}{clcc}
\hline Beach & \multicolumn{1}{c}{ Period } & Thermotolerant coliforms & CONAMA \\
\hline Holiday (RS) & 11 to $240 \mathrm{NMP} / 100 \mathrm{ml}$ & Excellent \\
Ajuruteua & School Vacation (DS) & 21 to $>1,100 \mathrm{NMP} / 100 \mathrm{ml}$ & Unsafe \\
& Holiday (DS) & 43 to $>1,100 \mathrm{NMP} / 100 \mathrm{ml}$ & Unsafe \\
\hline Bank Holiday (RS) & 3.6 to $23 \mathrm{NMP} / 100 \mathrm{ml}$ & Excellent \\
Pesqueiro & School vacation (DS) & 3.6 to $14 \mathrm{NMP} / 100 \mathrm{ml}$ & Excellent \\
& Bank Holiday (DS) & 23 to $460 \mathrm{NMP} / 100 \mathrm{ml}$ & Very good \\
\hline
\end{tabular}

